\title{
ПРАВОВА Й СОЦІАЛЬНА СУТНІСТЬ ТРАНСПОРТНИХ ЗЛОЧИНІВ
}

\author{
Федчун Н. $О$.
}

\begin{abstract}
У науковій статті досліджено правову й соціальну сутність транспортних злочинів. Установлено, що суспільно небезпечний характер злочинів, які посягають на безпеку функціонування (руху й експлуатації) транспорту визначається не тільки їх родовим об'єктом - громадською безпекою, а й тим, що їх предметом та/або засобом $\epsilon$ джерела підвищеної небезпеки, якими за своєю природою є транспортні засоби.
\end{abstract}

Ключові слова: транспортні злочини, громадська безпека, безпека функціонування транспорту, джерела підвищеної небезпеки, транспорт.

В научной статье исследована правовая и социальная сущность транспортных преступлений. Установлено, что общественно опасный характер преступлений, посягающих на безопасность функционирования (движения и эксплуатации) транспорта определяется не только их родовым объектом - общественной безопасностью, но и тем, что их предметом и/или средством являются, источники повышенной опасности, которыми по своей природе являются транспортные средства.

Ключевые слова: транспортные преступления, общественная безопасность, безопасность функционирования транспорта, источники повышенной опасности, трансnopm.

The aim of this article is to find out the legal and social nature of transport offences (crimes) by examining the essence of public safety relations that constitute a generic object and identifying transport as one of the important features of a given group of crimes.

The starting point for defining the social and legal nature of transport offences (crimes) should be the idea that these crimes encroach on public relations in the field of transport safety (traffic safety and safety of transport operations).

The transport safety includes a wide range of social relations, not only related to the accident-free transport operations, but also to the protection of human life and health, valuable property and the environment.

The peculiarity of crimes against transport safety (traffic safety and safety of transport operations) is that the harm to the individual (or property, or environment) is caused mainly by violation of the rules of use of high-risk sources.

Public safety implies certain public relations regarding the usage of sources of general danger that ensure the safety of human life and material values. Therefore, the socially dangerous nature of transport crimes is determined not only by their generic object - public safety, but also by their subject and/or means being, by their nature, potentially deadly sources that can be used as a means of destruction, causing harm.

Based on the above provisions, the conclusion can be made that traffic offenses (crimes) can be defined as criminal acts (acts or omissions) prescribed by the criminal law, namely: non-compliance or improper implementation of the rules against the public relations in the sphere of transport safety (traffic safety and safety of transport operations), that caused the occurrence of harmful effects or their threat.

Key words: transport offences (crimes), public safety, transport safety, high-risk sources, transport.

Федчун Н. О., 2019
Постановка проблеми та їі актуальність. Серед проблем, які безпосередньо стосуються забезпечення громадської безпеки, нагальною $€$ проблема безпеки функціонування транспорту. Безпека функціонування транспорту $\epsilon$ частиною національної безпеки країни, стан його розвитку відображає рівень цивілізації суспільства, а отже, актуалізує формування державної політики з убезпечення процесів, пов'язаних з використанням джерел підвищеної небезпеки - транспортних засобів, охороною життя й здоров'я людей, а також безпекою функціонування транспорту.

Забезпечення належного рівня безпеки функціонування транспорту $є$ одним з основних завдань сучасної держави. Це підтверджується увагою, що приділяється сьогодні в розвинених країнах світу питанням безпеки, зокрема й транспортної, і обумовлено величезним значенням транспорту для будь-якої сучасної країни.

Аналіз останніх досліджень та публікацій. Проблема забезпечення безпеки функціонування, а саме руху й експлуатації транспорту, $є$ достатньо складним явищем і вимагає взаємодії багатьох галузей знань. Дослідженнями кримінально-правових, кримінологічних та інших аспектів транспортних злочинів у різні роки займалися М.С. АлексєєВ, М.Г. Богатирьов, В.І. Борисов, В.І. Василенко, О.М. Джужа, В.І. Жульов, В.Є. Квашис, М.Й. Коржанський, І.В. Каретников, А.П. Копейченко, О.І. Коробєєв, І.Г. Маландін, В.А. Мисливий, Г.М. Надгорний, В.І. Осадчий, М.С. Романов та інші.

Метою статті $\epsilon$ з' ясування правової й соціальної сутності транспортних злочинів через дослідження змісту суспільних відносин громадської безпеки, що складають родовий об'єкт і визначення транспорту як однієї з важливих ознак цієї групи злочинів.

Виклад основного матеріалу. 3 розвитком транспорту підвищується потужність транспортних засобів і швидкість їх руху, що має важливе значення для розвитку суспільства. Проте це спричинює також негативні явища, оскільки більш тяжкими стають наслідки транспортних аварій, в яких гинуть люди, наноситься шкода матеріальним цінностям і довкіллю.

Поняття «транспортні злочини» не отримало чіткого визначення ні в кримінологічній науці, ні в теорії кримінального права. Більшість авторів зосередили свою увагу на аналізі окремих різновидів транспортних злочинів. Тому термінологія зводиться в основному до таких понять, як «злочинні порушення правил безпеки руху й експлуатації автомототранспорту і міського електротранспорту», «автотранспортні злочини», «дорожньо-транспортні злочини», «воднотранспортні злочини», «повітрянотранспортні злочини» тощо [1; $2 ; 3]$.

Вихідним моментом для визначення поняття транспортних злочинів має слугувати думка, що ці злочини посягають на суспільні відносини у сфері безпечного функціонування (руху й експлуатації) транспортних засобів. Безпека функціонування транспорту охоплює 
досить широке коло суспільних відносин, пов'язаних не тільки зі здійсненням безаварійної роботи транспортних засобів, але й з охороною життя та здоров'я людей, цінного майна, довкілля.

Саме терміном «безпека функціонування транспорту» можна доволі адекватно передати всю специфіку тих суспільних відносин, які становлять зміст цього поняття. Під безпекою функціонування транспорту розуміють такий стан транспортної діяльності, який унеможливлює заподіяння шкоди життю й здоров'ю людей, транспортним засобам, матеріальним цінностям, навколишньому природному середовищу й забезпечується заходами економічного, технічного, організаційного, соціального й правового характеру [3, с. 56-57].

В основі всіх правопорушень має бути щось спільне, що допомагало б, враховуючи кількісні та якісні характеристики цих явищ, розмежовувати їх на види. Такою загальною ознакою всіх правопорушень $\epsilon$, як відомо, їхня суспільна небезпека. Злочини відрізняються від інших правопорушень кількістю та якістю суспільної небезпеки.

Суспільна небезпека діяння має складний характер. Оскільки небезпечні для суспільства шкода або загроза заподіяння шкоди лише певним (а не будь-яким) об'єктам, остільки суспільна небезпека діяння перебуває поза ним самим. Оскільки ж шкода або загроза заподіяння шкоди певним об'єктам створюється лише певним (а не будь-яким) діянням, остільки суспільна небезпека діяння міститься в ньому самому (у діянні) [4, с. 16].

У зв'язку з таким станом речей у діянні можна виділити його фактичний склад і соціальну характеристику, тобто дію або бездіяльність і посягання на чинний правопорядок. Злочин завжди являє собою єдність факту та його кримінально-правової оцінки.

Можна зробити висновок, що критерієм віднесення злочинів проти безпеки функціонування транспорту до того чи іншого виду слугують ступінь (кількість) і характер (якість) суспільної небезпеки. Вони виражені в характері порушень відповідних правил безпеки, розмірі заподіяної шкоди, місці, часі, способі здійснення злочинних намірів, особливостях предмета, суб'єкта й суб'єктивної сторони.

Отже, на відміну від інших вчинків людини, злочином за своєю соціальною сутністю $€$ посягання на ті відносини, які склалися в суспільстві, що відображають найбільш важливі інтереси, унаслідок чого й охороняються кримінальним законом.

Кримінальна відповідальність за порушення правил безпеки руху й експлуатації транспорту передбачена розділом XI Особливої частини Кримінального кодексу України (ст. ст. 276-292).

Кримінальний кодекс України передбачає 18 норм, які структуровані відповідно до ступеня тяжкості злочинів, а також виду транспорту, з яким пов'язаний злочин. Так, першу групу становлять злочини, що вчиняються на водному, залізничному чи повітряному транспорті (ст. 276-285 КК України), другу - на автомобільному й міському електротранспорті (ст. 286-290 КК України), третю - з порушенням чинних на транспорті правил і пошкодженням магістральних трубопроводів (ст. ст. 291, 292 КК України).

Риси подібності й низка загальних типотвірних ознак розглянутих злочинів можна виявити в кожному елементі їх складів. Вирішальне значення для класифікації злочинів у галузі безпечного функціонування (руху й експлуатації) транспортних засобів має об'єкт посягання. Основне значення об'єкта злочину визначається його роллю в структурі складу злочину, а також наявністю у визначенні злочину матеріальної ознаки: не може бути злочинним те діяння, яке не спричиняє й не становить загрози спричинення шкоди об'єктам кримінально-правової охорони. Отже, немає злочинів без об'єкта посягання. Встановлення й аналіз змісту об'єкта дає змогу дати відповідь на запитання, які стосуються сутності охоронюваного блага, уточнення меж дії кримінально-правової норми. Об'єкт злочину є тією ознакою, яка дає можливість проводити розмежування злочинів для їх кваліфікації. Крім того, встановлення спричинення суттєвої шкоди об'єкту кримінально-правової охорони дає змогу відділити злочини від інших правопорушень й аморальних проступків.

Слід зазначити, що автор дотримується погляду щодо визнання об'єктом злочину суспільних відносин, що охороняються кримінальним законом, порушення яких спричиняє суспільно-небезпечну шкоду.

Особливістю злочинів, що посягають на безпеку функціонування (руху й експлуатації) транспортних засобів, $\epsilon$ те, що шкода особі (або майну, або середовищу існування) заподіюється в основному в разі порушення правил використання джерел підвищеної небезпеки.

Саме громадська безпека передбачає щодо поводження 3 джерелами загальної небезпеки певні суспільні відносини, які забезпечують збереження людей і матеріальних цінностей [5, с. 103]. Отже, суспільно небезпечний характер визначається не тільки родовим об'єктом - громадською безпекою, а й тим, що предметом та/або засобом $є$ за своєю природою потенційно смертоносні джерела, які можуть бути використані як засоби руйнування, заподіяння шкоди.

Технічні й правові норми визначають порядок поводження з транспортними засобами. У сучасних умовах громадська безпека - уже не стільки мета, як доцільна діяльність, що застосовує певні засоби й породжує певний результат. Невиконання спеціальних правил обачності під час використання транспортних засобів створює небезпеку для життя й здоров'я людей [6, с. 51].

Загалом термін «безпека» означає відсутність небезпеки й наявність стану захищеності життєво важливих інтересів індивіда, суспільства, держави від внутрішніх і зовнішніх загроз. Онтологічний аспект цього аналізу трактує «безпеку» як певну якість буття людини, що визначає мету й результат діяльності людини щодо захисту від загрозливих чинників, подій та явищ [7, с. 10].

Варто підкреслити, що громадська безпека органічно пов'язана з особистою безпекою громадян, яка становить комплекс суспільних інтересів, спрямованих на захист конституційних прав і свобод людини й громадянина. Іншими словами громадська безпека - це захищеність життєво важливих інтересів окремих громадян, соціальних груп, суспільства загалом, а також системи суспільних цінностей від внутрішніх і зовнішніх загроз політичного, економічного, соціального, екологічного та іншого характеру. Водночас головний суспільний інтерес полягає в дотриманні безпеки кожної особистості, забезпеченні добробуту, стабільності інститутів, що гарантують демократію, безпеку та стійкий розвиток суспільства. 
Отже, громадська безпека як родовий об'єкт транспортних злочинів - це система суспільних відносин, які забезпечують захищеність життєдіяльності, запобігають загрозам природного існування людей, позбавлення їх життя і здоров'я.

У цьому контексті під безпекою функціонування (руху й експлуатації) транспорту заведено розуміти таку діяльність учасників руху транспортних засобів чи підготовки транспортного засобу або іншу участь у русі транспорту, яка унеможливлює спричинення шкоди життю чи здоров'ю людини або майнової шкоди в результаті належного виконання чинних на транспорті правил.

Так, В.О. Навроцький під безпекою руху й експлуатації розуміє відсутність небезпеки, тобто такий стан, за якого не заподіюється й не може бути заподіяна шкода життю й здоров'ю людей, власності, іншим соціальним цінностям внаслідок руху або експлуатації джерел підвищеної небезпеки транспортних засобів відповідних видів, а також функціонування матеріальної інфраструктури об'єктів транспорту [8, с. 769].

Слід погодитися з В.І. Борисовим, який, розглядаючи питання про механізм заподіяння шкоди відносинам безпеки виробництва, визнає, що шкода додатковим об'єктам - життю, здоров'ю, власності заподіюється опосередковано через основний об'єкт [9, с. 27]. Крім основного безпосереднього в аналізованих злочинах додатковими об'єктами є особистість, власність.

Зокрема, у разі взаємодії з транспортним засобом особа зобов'язана дотримуватися правил безпеки, за якими необхідно додержуватися спеціальних правил безпеки руху й експлуатації транспортного засобу. Порушуючи ці обов'язки, особа розриває соціальні зв'язки в суспільних відносинах, дезорганізує керування транспортом, що призводить до зменшення транспортної безпеки й створює або посилює ймовірність заподіяння шкоди додатковим об'єктам.

Визнаючи громадську безпеку ширшим поняттям, ніж безпека функціонування (руху й експлуатації) транспорту, можна зайняти позицію визнання останньої безпосереднім об'єктом, а громадської безпеки - родовим.

Таким чином, громадська безпека як родовий об'єкт злочинів проти безпеки руху й експлуатації транспорту являє собою систему однорідних суспільних відносин, які забезпечують стан захищеності життєдіяльності, запобігають загрозам природного існування людей, а суспільні відносини, що виникають з приводу забезпечення безпеки функціонування транспорту в суспільстві загалом і між громадянами, за якої гарантується відсутність загрози спричинення шкоди невизначеному колу осіб, є видовим об'єктом зазначених злочинів.

Правильне розуміння специфіки транспортних злочинів передбачає точне визначення й транспортного засобу як однієї з важливих ознак цієї групи злочинів.
Складність проблеми обумовлена відсутністю єдиного поняття «транспортний засіб»у технічній і юридичній літературі, конструктивними особливостями кримінально-правових норм, які містять різні критерії оцінки транспортних засобів як ознаки відповідних складів злочинів, а також встановленням відповідальності за порушення правил безпеки під час використання не тільки механічних, але й у ряді випадків немеханічних транспортних засобів.

Під «транспортом» (від лат. transporto - перевозити, переміщувати) у спеціальній літературі розуміють: а)виробничо-технологічнийтранспортнийкомплексзпідприємствами й установами виробничого й соціального призначення, що йому належать; б) транспортний засіб, призначений для перевезення людей і (або) вантажів.

У кримінальному праві термін «транспорт» використовується в другому його значенні, як синонім транспортного засобу. У найзагальнішому сенсі до транспортних засобів слід віднести різні види залізничного, повітряного, морського, річкового транспорту, а також всі види автомобілів, трактори та інші самохідні машини, трамваї, тролейбуси, мотоцикли та інші механічні транспортні засоби. Аналіз відомчих нормативних актів допомагає дати більш розгорнуту характеристику кожного з названих видів транспорту.

Отже, єдність родового об'єкта аналізованих злочинів, низка загальних ознак і рис дають підставу для виділення цих злочинів у відносно самостійну групу, що дає змогу комплексно дослідити їх з практичною метою подальшого підвищення ефективності кримінального права як інструменту боротьби зі злочинністю, а саме вдосконалення чинного кримінального законодавства, практики його застосування, шляхів і напрямів діяльності щодо забезпечення протидії транспортним злочинам.

Висновки. Виходячи з вищенаведених міркувань, можна зробити висновок, що безпека функціонування транспорту $є$ складовою частиною відносин громадської безпеки. Ці відносини є родовим об'єктом злочинів проти безпеки руху й експлуатації транспорту.

Отже, транспортні злочини можна визначити як передбачені кримінальним законом суспільно небезпечні діяння (дії або бездіяльність), а саме: невиконання або неналежне виконання чинних на транспорті правил, що посягають на суспільні відносини у сфері безпечного функціонування (руху й експлуатації) транспортних засобів, спричинили шкідливі наслідки або створили загрозу їх настання.

Більше того, суспільно небезпечний характер транспортних злочинів визначається не тільки їх родовим об'єктом - громадською безпекою, а й тим, що їх предметом та/або засобом $\epsilon$ потенційно смертоносні за своєю природою джерела, які можуть бути використані як засоби руйнування, заподіяння шкоди. 


\section{Література}

1. Мисливий В.А. Злочини проти безпеки дорожнього руху та експлуатації транспорту : монографія / В.А. Мисливий. - Дніпропетровськ : Юрид. акад. Мін-ва внутр. справ, 2004. 360 с.

2. Осадчий В.І. Злочини проти безпеки руху та експлуатації транспорту : монографія / В.І. Осадчий. Київ, 2011. $150 \mathrm{c}$.

3. Коробеев А.И. Транспортные преступления / А.И. Коробеев. Санкт-Петербург : Изд-во Юридический центр Пресс, 2003. 406 с.

4. Коган В.М. Социальные свойства преступности : учебное пособие / В.М. Коган. Москва, 1977. 90 с.

5. Тихий В. П. Уголовно-правовая охрана общественной безопасности / В.П. Тихий. Харьков : Основа, 1981. 234 с.

6. Федчун Н.О. Кримінологічна безпека мореплавства та кримінально-правові засоби іï забезпечення: дис. ... канд. юрид. наук : 12.00 .08 / Н.О. Федчун. Одеса : НУ ОЮА, 2014. 241 с.
Протидія злочинності: проблеми практики та науково-методичне забезпечення

7. Горбулін В.П. Національна безпека: український вимір / В.П. Горбулін, О.В. Литвиненко ; Інститут проблем національної безпеки Ради національної безпеки і оборони України. Київ : Інтертехнологія, 2008. 104 с.

8. Науково-практичний коментар Кримінального кодексу України. 6-те вид., переробл. та доповн. / За ред. М.І. Мельника, М.І. Хавронюка. Київ : Юридична думка, 2009. 1184 с.

9. Борисов В.И. Основные проблемы охраны безопасности производства в уголовном законодательстве Украины : автореф. дисс. ... д-ра юрид. наук : 12.00.09. Харьков, 1993. 34 с.

Федчун Н. О., кандидат юридичних наук, дочент кафедри кримінології та кримінально-виконавчого права Національного університету «Одеська юридична академія» 